\title{
KESENJANGAN INVESTASI DAN EVALUASI KEBIJAKAN PEMEKARAN WILAYAH DI INDONESIA
}

\author{
Imamudin Yuliadi \\ Fakultas Ekonomi Universitas Muhammadiyah Yogyakarta \\ Jalan Lingkar Selatan, Tamantirto, Kasihan, Bantul, Yogyakarta, Indonesia, Telepon:+62-274-387656 \\ E -mail: imamudin2006@yahoo.co.id
}

Diterima 13 Januari 2012/ Disetujui 16 Agustus 2012

\begin{abstract}
The development of local participation and economic potential is the aim of the policy of regional autonomy through regional expansion. The policy of regional expansion also brings new problems such as the problem of economic and bureaucratic burden that must be borne by the government and local communities. This study used some formulas to describe the objects of the research that has been established regarding the economic potential of the region, SMEs and entrepreneurship, investment gap and fiscal gap. To explain the policy implications of the expansion of the region to economic justice, then the economic analysis in this research comes with regional economic and investment disparities study. The object of this study is the province of Gorontalo which is a result of the policy of regional expansion. This research is a descriptive-analytic because in addition to get an overview of each condition variable such research, as well as to know the relation between the variables in the study.
\end{abstract}

Keywords: expansion area, economic decentralization, economic gap, general allocation fund

\begin{abstract}
Abstrak: Pengembangan partisipasi dan potensi ekonomi daerah merupakan tujuan dari kebijakan otonomi daerah melalui pemekaran wilayah. Di sisi lain kebijakan pemekaran wilayah juga membawa masalah baru yang tidak ringan yaitu beban ekonomi dan birokrasi yang harus diemban pemerintah dan masyarakat daerah. Penelitian ini menggunakan beberapa formula untuk menjelaskan obyek-obyek penelitian yang telah ditetapkan menyangkut potensi ekonomi daerah, UMKM dan kewirausahaan, kesenjangan investasi, dan kesenjangan fiskal. Untuk menjelaskan sejauhmana implikasi kebijakan pemekaran wilayah terhadap keadilan ekonomi, maka analisis ekonomi dalam penelitian ini dilengkapi dengan studi kesenjangan investasi dan ekonomi daerah. Obyek penelitian ini adalah provinsi Gorontalo yang merupakan hasil dari kebijakan pemekaran wilayah. Penelitian ini bersifat deskriptif-analitis karena selain untuk mendapatkan gambaran kondisi masing-masing variabel penelitian tersebut juga untuk mengetahui kaitan antarvariabel dalam penelitian.
\end{abstract}

Kata kunci: pemekaran wilayah, desentralisasi ekonomi, kesenjangan ekonomi, dana alokasi umum

\section{PENDAHULUAN}

Kesenjangan ekonomi antara pusat dan daerah menjadi pemicu lahirnya semangat otonomi daerah dan tuntutan untuk pemekaran wilayah di beberapa daerah di Indonesia. Kebijakan sentralisasi di era orde baru membawa dampak pada pertumbuhan ekonomi yang tidak merata antardaerah di Indonesia, antara Jawa dengan luar Jawa, antara kawasan barat Indonesia (KABARI) dengan kawasan timur Indonesia (KATIMIN) dengan segala implikasinya. Arus reformasi membawa angin segar bagi peningkatan partisipasi ekonomi dan politik seluruh komponen masyarakat di Indonesia termasuk keinginan pemekaran wilayah sebagai bagian dari kebijakan otonomi daerah. Kebijakan otonomi daerah menjadi salah satu semangat re- 
formasi untuk mendorong potensi ekonomi daerah meskipun akhir-akhir ini perlu ada evaluasi secara menyeluruh menyangkut efektivitas dan efisiensi kebijakan pemekaran wilayah dalam rangka peningkatan potensi ekonomi daerah. Otonomi daerah pada hakekatnya adalah suatu keadaan yang memungkinkan daerah dapat mengaktualisasikan segala potensi terbaik yang dimilikinya secara optimal. Eksplorasi dan eksploitasi potensi ekonomi daerah dimungkinkan manakala ada kewenangan dari unsur-unsur di daerah untuk memanfaatkan potensinya. Namun persoalannya ternyata cukup kompleks karena kecurigaan dan kekhawatiran terjadinya disintegrasi menjadi alasan pemerintah pusat untuk secara hati-hati merumuskan kebijakan otonomi daerah seperti dalam rumusan UU No.25 tahun 1999 yang dianggap tidak selaras dengan UU No.22 tahun 1999 karena pemberian kewenangan yang cukup besar tidak diimbangi dengan perubahan mendasar dalam rangka penguatan dari sisi pendanaan

Pemekaran wilayah provinsi Gorontalo dari provinsi Sulawesi Utara tidak lepas kebijakan pemekaran wilayah yang diterapkan pemerintah di era reformasi ini.. Kekhawatiran akan munculnya kekuatan disintegrasi yang menunggangi semangat otonomi daerah menjadi alasan mengapa persoalan otonomi daerah dirumuskan dengan sangat hati-hati dan sifatnya gradual di samping mempersiapkan kelengkapan unsur-unsur penunjang di daerah.

Kerangka Teori dan Kajian Pustaka. Pembangunan ekonomi mempunyai makna peningkatan kapasitas ekonomi untuk meningkatkan kemampuan perekonomian dalam memenuhi kebutuhan masyarakat. Pembangunan ekonomi juga diartikan sebagai peningkatan kualitas kehidupan masyarakat melalui peningkatan pelayanan masyarakat. Pembangunan ekonomi juga diartikan sebagai peningkatan partisipasi dan keterlibatan masyarakat dalam proses pembangunan sehingga terwujud peningkatan kesejahteraan dan keadilan ekonomi masyarakat. Untuk mendorong pertumbuhan ekonomi dan pembangunan membutuhkan investasi baik dari kalangan pemerintah maupun swasta. Investasi dalam perekonomi merupakan motor peng- gerak yang dapat memperluas kapasitas produksi dan sekaligus meningkatkan kesejahteraan ekonomi masyarakat melalui penciptaan lapangan kerja. Hal ini menunjukkan bahwa peranan investasi di samping dapat mempercepat pertumbuhan ekonomi juga sekaligus dapat menciptakan pemerataan pendapatan dan lapangan kerja. Peranan investasi dalam perekonomian yaitu untuk mendorong pertumbuhan ekonomi sehingga dapat meningkatkan kapasitas produksi, meningkatkan kualitas produk dan penciptaan lapangan kerja. Melalui investasi maka kegiatan ekonomi dapat berkembang dan kesejahteraan masyarakat dapat semakin meningkat. Jadi investasi merupakan salah satu prasyarat yang harus dipenuhi bagi suatu perekonomian yang sedang membangun di samping faktor pertumbuhan penduduk dan kemajuan teknologi.

Penelitian yang dilakukan oleh Pramono Hadi (2009) tentang hubungan antara pertumbuhan ekonomi, distribusi pendapatan dan kemiskinan di Jawa Tengah. Penelitian ini mengungkapkan adanya relasi dan dinamika dalam proses pembangunan ekonomi di samping meningkatkan kesejahteraan masyarakat juga diikuti oleh munculnya persoalan tentang distribusi pendapatan dan maraknya kemiskinan di masyarakat. Kualitas SDM dan kurangnya infrastruktur menjadi faktor pemicu munculnya kesenjangan ekonomi antarwilayah dalam proses pembangunan.

Penelitian yang dilakukan oleh Roy W Bahl (1997) tentang evaluasi dampak reformasi fiskal intrapemerintah di Cina menyatakan bahwa reformasi fiskal secara menyeluruh di Cina pada tahun 1994 mengubah struktur pajak-pajak penting, mengubah tanggungjawab administrasi perpajakan dan menyempurnakan pengaturan-pengaturan bagi hasil. Selain itu dilakukan pemangkasan kemampuan daerah untuk melakukan pendekatan-pendekatan dalam memobilisasi dana. Isu penting dari penelitian tersebut adalah porsi penerimaan daerah setelah pembagian menjadi bertambah besar. Ada beberapa alasan mengapa hal itu terjadi yaitu pertama, formula pembagian yang dilaksanakan tahun 1988 dapat dinogsiasikan untuk lebih menguntungkan pemerintah daerah. Ke- 
dua, kinerja ekonomi yang buruk dan benca alam tidak memungkinkan pemerintah daerah untuk mencapai jumlah yang telah ditetapkan. Ketiga, pemerintah daerah menggunakan kewenangannya untuk memberikan konsesi pajak dan kontrak yang menguntungkan dan hal ini mengurangi aliran penerimaan ke pemerintah pusat.

Nano Prawoto, dkk (2010) melakukan penelitian tentang penangangan kawasan tertinggal di Jawa Tengah melalui peningkatan kapasitas ekonom dan penyediaan infrastruktur yang dapat medorong pertumbuhan ekonomi dan arus distribusi barang ke daerah-daerah. Penanganan daerah terasing memerlukan keterpaduan antarinstansi pemerintah dan pengusaha dalam meningkatkan partisipasi ekonomi masyarakat setempat. Ketersediaan infrastruktur jalan dan jembatan menjadi kendala utama dalam menyelesaikan persoalan pembangunan ekonomi pada masyarakat terasing. Permasalahan produksi dan distribusi bahan pangan dan barang modal menjadi kendala utama untuk mengatasi keterisolasian masyarakat terasing.

Francois Vaillancourt (1996) melalui kajian tentang aspek pendanaan infrastruktur pada keuangan pemerintah daerah di Maroko dan Tunisia. Penelitian ini mengkaji mengenai masalah system pendanaan sektor investasi lokal. Tarif pajak yang dipungut secara terpusat ditetapkan oleh pemerintah pusat sedangkan tarif pajak daerah ditetapkan secara terpusat atau lokal tetapi masih dalam interval yang ditetapkan pusat. Transfer dana dari pusat ke daerah memiliki dua peran utama yaitu pertama, dana ini dapat digunakan untuk meningkatkan penyediaan pelayanan tertentu dimana daerah tidak mampu memenuhi secara baik. Kedua, dana ini digunakan untuk pemerataan potensi pajak di antara pemerintah-pemerintah daerah.

Ernesto Rezk (1996) melakukan penelitian tentang federalisme fiskal dan desentralisasi di Argentina. Desentralisasi pengeluaran terutama berlangsung melalui delegasi yang bersama konsentrasi pemungutan pajak yang demikian besar pada pusat menggiring derajat otonomi keuangan ke arah lebih kecilnya bagian subnasional dan pertanggungjawaban fiskalpun beralih tangan dikarenakan akuntabilitas yang melekat pada sumber penerimaan. Sistem bagi hasil merupakan mekanisme koordinasi pajak yang lebih disukai di Argentina tidak saja antara pusat dan provinsi tapi juga antara provinsi dan Dati II.

Untuk mengatasi persoalan pembangunan di daerah pemekaran, maka perlu dirumuskan strategi untuk mempercepat pembangunan infrastruktur dan peningkatan kualitas SDM di daerah. Strategi untuk mengundang investor asing (PMA) ke daerah merupakan langkah strategi sekaligus cukup berat karena menuntut kesiapan semua instansi terkait baik di pusat maupun di daerah. Ketersediaan infrastruktur seperti jalan, jembatan, listrik, air minum, jaringan telekomunikasi menjadi kendala utama dalam menarik investor asing ke daerah. Adanya kepastian hukum menyangkut pajak, ijin usaha, pemanfaatan lahan juga menjadi kendala paling besar dalam mendorong masuknya investasi asing di daerah. Kesenjangan investasi sebagai dampak kebijakan pemekaran wilayah harus direspon dengan strategi pembangunan ekonomi daerah yang berwawasan penguatan ekonomi rakyat melalui dukungan pemerintah dalam bentuk penyediaan fasilitas infrastruktur, kredit keuangan, fasilitas pemasaran, dan sebagainya, sehingga dapat mewujudkan peningkatan kesejahteraan bagi masyarakat di daerah.

\section{METODE PENELITIAN}

Data yang dikumpulkan dalam penelitian ini merupakan data sekunder dari sumber-sumber yang kredibel. Di samping itu untuk mendukung kedalaman analisis penelitian ini juga mempertimbangkan hasil-hasil kajian dan penelitian lain yang relevan. Pengumpulan data sekunder dilakukan dengan teknik dokumentasi dan kompilasi data yang diperoleh dari berbagai sumber data dan laporan realisasi pembangunan daerah seperti Badan Pusat Statistik (BPS), Bank Indonesia (BI), Bappeda dan kantor-kantor dinas yang terkait.

\section{Metode Analisis Data}

Metode analisis data dalam penelitian dilaku- 
kan dengan menggunakan beberapa metode analisis yaitu analisis kesenjangan investasi, analisis regresi dan analisis kesenjangan fiskal. Model analisis kesenjangan investasi sebagai berikut:

$r=\left(I_{i}-I\right)^{2} x \frac{f_{i}}{n}$

dimana:

r adalah tingkat ketimpangan investasi di provinsi -i, $\mathbf{I}_{\mathbf{i}}$ adalah nilai investasi di provinsi $\mathbf{i}, \mathbf{I}$ adalah Nilai investasi total, $\mathbf{f}_{\mathbf{i}}$ adalah jumlah penduduk di provinsi $-\mathbf{i}, \mathbf{n}$ adalah jumlah total penduduk.

Dari formulasi tersebut dapat diketahui implikasi kebijakan pemekaran wilayah terhadap kesenjangan investasi di provinsi Gorontalo, sehingga dapat dirumuskan langkah strategis untuk mengatasi masalah tersebut.

\section{Analisis Perekonomian di Provinsi Gorontalo}

Latar Belakang Sejarah dan Kondisi Geografis. Provinsi Gorontalo merupakan pemekaran dari provinsi Sulawesi Utara yang terletak di jazirah utara pulau Sulawesi dan merupakan salah satu dari tiga provinsi di Indonesia yang terletak di utara garis katulistiwa. Berdasarkan UU No. 38 tahun 2001 bahwa provinsi Gorontalo ditetapkan sebagai provinsi ke-32 lepas dari provinsi Sulawesi Utara. Batas wilayah provinsi Gorontalo adalah sebelah utara Laut Sulawesi, samudera pasifik dan Republik Philipina, sebelah timur dengan provinsi Sulawesi Utara, sebelah selatan Teluk Tomini dan sebelah barat provinsi Sulawesi Tengah. Gorontalo menurut sejarah telah ada sejak 400 tahun yang lalu dan merupakan kota tertua di samping kota Makasar, Pare-pare, dan Manado. Sejak awal berdirinya Gorontalo menjadi pusat penyebaran agama Islam di Indonesia timur yaitu dari Ternate, Bone, dan Gorontalo. Sebelum Indonesia merdeka pada tanggal 17 Agustus 1945, masyarakat Gorontalo telah memproklamirkan kemerdekaan pada tanggal 23 Januari 1942. Setelah Indonesia merdeka maka rakyat Gorontalo menyatakan diri bergabung dengan NKRI.

Wilayah provinsi Gorontalo meliputi da- ratan dan lautan di mana sebagian besar wilayah dataran terdiri dari pegunungan dan bukitbukit yang diselingi lembah yang membentuk dataran. Luas provinsi Sulawesi Utara 12.215,45 $\mathrm{km}^{2}$ yang terbagi dalam beberapa daerah kabupaten/kota. Wilayah provinsi Gorontalo terletak pada ketinggian 0-2.400 $\mathrm{m}$ dpa dengan jumlah pulau-pulau kecil yang mengitarinya sebanyak 67 buah. Provinsi ini mempunyai garis pantai sepanjang $590 \mathrm{~km}$ dengan luas teritorial $10.500 \mathrm{~km}^{2}$ dan luas daerah zone ekonomi eksklusif (ZEE) $40.000 \mathrm{~km}^{2}$. Wilayah provinsi Gorontalo ada pada mulut Laut Pasifik yang menghadap negara Korea, Jepang, dan Amerika latin. Wilayah ini sangat strategis ditinjau dari aspek pengembangan ekonominya karena terletak di antara 2 daerah kawasan pembangunan terpadu (KAPET) yaitu Batui di Sulawesi Tengah dan Bitung - Manado di Sulawesi Utara. Kondisi geografis ini membuka peluang cukup besar bagi daerah Gorontalo untuk berkembang karena dilalui lalu lintas barang dan manusia dari berbagai wilayah pertumbuhan.

Iklim di wilayah Gorontalo secara garis besar ada dua macam yaitu kemarau dan penghujan jadi termasuk daerah tropis yang dipengaruhi oleh angin muson. Curah hujan terjadi pada bulan Maret, Mei dan Oktober tidak merata dengan angka tahunan berkisar antara 207,77 mm dan jumlah hari hujan 90 - 139 hari. Suhu udara rata-rata $23-31^{\circ} \mathrm{C}$. Tekanan udara berkisar 11.21.5 MOB dengan kecepatan angin ratarata 1,9 knot.

Keadaan Ekonomi. Struktur perekonomian di provinsi Gorontalo ditinjau dari kontribusi sektor-sektor ekonomi lebih banyak di topang oleh sektor industri dan jasa. Sedangkan peranan sektor pertanian relatif stabil. Tabel 1 menjelaskan struktur ekonomi provinsi Gorontalo.

Angka pada Tabel 1 menunjukkan bahwa struktur ekonomi di Gorontalo didominasi sektor pertanian (30 persen) dan jasa (20,9 persen). Pengembangan sektor agribisnis menjadi andalan utama provinsi ini, mengingat kondisi alam dan kultur masyarakat yang paham betul mengenai bagaimana potensi dan pengembangan sektor agribisnis. Pengembangan sektor pertanian juga dikaitkan dengan peningkatan nilai 
Tabel 1. Produk Domestik Regional Bruto (PDRB) Provinsi Gorontalo Menurut Lapangan Usaha Atas Dasar Harga Konstan 2000 (Juta Rupiah)

\begin{tabular}{lrrrr}
\hline \multicolumn{1}{c}{ Lapangan Usaha } & \multicolumn{3}{c}{ Tahun } \\
\cline { 2 - 5 } & \multicolumn{1}{c}{$\mathbf{2 0 0 3}$} & $\mathbf{2 0 0 4}$ & $\mathbf{2 0 0 5}$ & $\mathbf{2 0 0 6}$ \\
\hline Pertanian & 557.678 & 575.307 & 618.182 & 667.260 \\
Pertambangan dan Penggalian & 16.871 & 17.438 & 19.122 & 21.274 \\
Industri Pengolahan & 175.163 & 184.178 & 192.882 & 181.447 \\
Listrik, Gas dan Air Bersih & 10.546 & 11.804 & 12.446 & 12.640 \\
Bangunan & 136.057 & 142.126 & 149.000 & 167.512 \\
Perdagangan Besar, Eceran, Rumah makan dan Hotel & 262.173 & 268.830 & 281.981 & 301.344 \\
Pengangkutan dan Komunikasi & 152.938 & 187.254 & 204.781 & 224.738 \\
Keuangan, Persewaan dan Jasa Perusahaan & 148.773 & 178.719 & 172.323 & 185.139 \\
Jasa-jasa & 308.990 & 326.106 & 377.007 & 414.462 \\
Jumlah & 1.769 .188 & 1.891 .763 & 2.027 .723 & 2.175 .816 \\
\hline
\end{tabular}

Sumber: BPS, Gorontalo dalam Angka, 2007

tambah produk pertanian melalui industri pengolahan produk pertanian seperti jagung sehingga masyarakat benar-benar merasakan manfaat dalam mengembangkan sektor pertanian ini. Sektor jasa juga menjadi andalan dari provinsi Gorontalo terutama pengembangan sektor pariwisata dan sektor-sektor lain yang terkait seperti hotel, rumah makan, dan jasa transportasi. Keadaan ini bisa dimaklumi mengingat Gorontalo - seperti halnya provinsi Sulawesi Utara - merupakan salah satu daerah tujuan wisata andalan khususnya wisata bahari. Pada tahun 2004 kontribusi sektor jasa sebesar 20,92 persen dan tahun 2005 meningkat tajam menjadi 26,31 persen. Pada tahun-tahun selanjutnya mengalami penurunan yaitu sebesar 24,95 persen pada tahun 2006 dan 24,84 persen pada tahun 2007.

Secara umum kebijakan pemekaran wilayah menjadi provinsi baru ke-32 benar-benar memberikan manfaat bagi masyarakat. Keadaan ini bisa dibuktikan secara langsung melalui angka-angka dalam PDRB yang terus meningkat pascakebijakan pemekaran wilayah. Nilai PDRB atas dasar harga berlaku tahun 2000 menunjukkan kinerja yang positif dimana pada tahun 2003 sebesar Rp1.769.188 juta kemudian pada tahun 2004 meningkat menjadi Rp1.891.763 juta. Bahkan pada tahun 2006 dan 2007 meningkat tajam menjadi Rp2.027.723 juta dan Rp2.175.816 juta. Fenomena ini memberikan bukti konkret mengenai keberhasilan kebijakan pemekaran wilayah bagi daerah-daerah lain bahwa kebijakan ini menjadi terobosan strategis dalam mendorong potensi ekonomi daerah dan meningkatkan kesejahteraan masyarakat

Pada data Tabel 1 juga menunjukkan bahwa kontribusi sektor listrik, gas, dan air bersih paling kecil dibandingkan sektor-sektor lainnya di samping sektor pertambangan dan penggalian. Pada tahun 2003 kontribusi sektor listrik, gas dan air minum sebesar Rp10.546 juta kemudian pada tahun 2004 meningkat menjadi Rp11.804 juta. Keadaan ini memberikan sinyal bagi pengambil kebijakan di daerah dan pusat bahwa persoalan infrastruktur menjadi hal penting dalam mendorong pertumbuhan ekonomi di daerah. Salah satu pertimbangan para investor adalah ketersediaan infrastruktur untuk menunjang pengembangan sektor industri pengolahan.

Investasi di Gorontalo. Aktivitas investasi di Gorontalo mengalami pasang surut pascakebijakan pemekaran wilayah. Nilai investasi bisa dilihat dari besarnya investasi menurut sektorsektor ekonomi dan juga bisa dianalisis berdasarkan sifat atau asal investasi yang telah disetujui pemerintah baik PMDN maupun PMA. Nilai PMDN yang telah disetujui pemerintah di provinsi Gorontalo dapat dilihat pada Tabel 2.

Dari Tabel 2 terlihat bahwa nilai investasi PMDN yang disetujui pemerintah dari tahun 2000 sampai tahun 2006 kurang menguntungkan. Nilai investasi PMDN pada tahun 2001 sebesar Rp1.709,4 milyar namun pascakebijakan pemekaran wilayah pada tahun 2001 iklim investasi di Gorontalo benar-benar kurang memuaskan. Hampir tidak ada investor daerah 
Tabel 2. Nilai Investasi PMDN yang Disetujui Pemerintah di Gorontalo (Milyar rupiah)

\begin{tabular}{ccccccccc}
\hline Tahun & 2000 & 2001 & 2002 & 2003 & 2004 & 2005 & 2006 & 2007 \\
\hline Investasi & - & $1.709,4$ & - & - & 0,7 & - & - & - \\
\hline
\end{tabular}

Sumber: BPS, Indikator Ekonomi

yang berinvestasi di Gorontalo kecuali pada tahun 2004 yang nilainya sebesar Rp0,7 milyar. Keadaan ini menyiratkan bahwa kebijakan pemekaran wilayah benar-benar menimbulkan persoalan dalam upaya mendorong investasi di Gorontalo khususnya investasi PMDN. Ada beberapa kemungkinan mengapa investasi PMDN pascakebijakan pemekaran wilayah di Gorontalo kurang menggembirakan yaitu (1) Selama ini kebijakan dan aturan menyangkut investasi diatur oleh pemerintah Sulawesi Utara di Manado sehingga investasi PMDN lebih banyak dikendalikan dan diarahkan di kawasan Sulawesi Utara dibandingkan ke Gorontalo, (2) Minimnya sarana dan prasarana infrastruktur penunjang investasi di Gorontalo. Keadaan ini dianggap kurang memberikan insentif bagi para pengusaha domestik untuk berinvestasi di Gorontalo meskipun sebenarnya potensi ekonominya cukup besar.

Sedangkan nilai investasi PMA di Gorontalo relatif lebih positif dan stabil dibandingkan nilai investasi PMDN meskipun nilainya kecil. Tabel 3 menjelaskan perkembangan investasi PMA di Gorontalo dari tahun 2000 sampai 2007.

Data tabel nilai investasi PMA yang disetujui pemerintah pascakebijakan pemekaran wilayah provinsi Gorontalo pada tahun 2000 sebesar Rp0,2 milyar. Namun pada tahun 2001 nilai investasi PMA nihil sampai dengan tahun 2002. Fakta ini menunjukkan bahwa kebijakan pemekaran wilayah provinsi Gorontalo dari provinsi Sulawesi Utara pada tahun-tahun awal kurang menggembirakan dalam upaya mendorong investasi PMA di daerah ini. Namun pada tahun 2004 sampai tahun 2007 nilai investasi PMA relatif cukup menggembirakan. Pada tahun 2004 nilai investasi PMA sebesar Rp85,6 milyar artinya ada peningkatan yang cukup besar, kemudian pada tahun 2005 turun lagi menjadi Rp3,5 milyar dan meningkat lagi pada tahun 2006 menjadi Rp14,6 milyar. Fakta tersebut menegaskan bahwa kebijakan pemekaran wilayah relatif memberi dampak yang cukup bermakna dalam jangka menengah yaitu 3-4 tahun. Keadaan ini dimungkinkan karena adanya reformasi di bidang perdagangan dan investasi yang memberikan kemudahan bagi para investor dalam berinvestasi. Data tersebut menunjukkan bahwa kebijakan pemekaran wilayah provinsi Sulawesi Utara menjadi provinsi Gorontalo berdampak signifikan terhadap penurunan investasi PMA pada tahun-tahun awal, tapi kemudian ada peningkatan PMA karena adanya restrukturisasi dan reorganisasi dalam tata laksana pemerintahan.

Analisis Kesenjangan Investasi PMDN di Gorontalo. Pemekaran wilayah provinsi Gorontalo dari provinsi Sulawesi Utara pada tahun 2001 membawa perubahan yang sangat berarti baik pada perekonomian di Sulawesi Utara maupun di Gorontalo khususnya menyangkut upaya untuk mendorong iklim investasi baik PMA maupun PMDN. Untuk mengetahui dampak kebijakan pemekaran wilayah terhadap kesenjangan investasi, maka perlu dianalisis dengan menggunakan formulasi sebagai berikut:

$r=\left(I_{i}-I\right)^{2} \times \frac{f_{i}}{n}$

Tabel 3. Nilai Investasi PMA yang Disetujui Pemerintah di Gorontalo (Milyar rupiah)

\begin{tabular}{ccccccccc}
\hline Tahun & $\mathbf{2 0 0 0}$ & $\mathbf{2 0 0 1}$ & $\mathbf{2 0 0 2}$ & $\mathbf{2 0 0 3}$ & $\mathbf{2 0 0 4}$ & $\mathbf{2 0 0 5}$ & $\mathbf{2 0 0 6}$ & $\mathbf{2 0 0 7}$ \\
\hline Investasi & 0,2 & - & - & 0,1 & 85,6 & 3,5 & 14,6 & 1,6 \\
\hline Sumber: BPS, Indikator Ekonomi
\end{tabular}


di mana:

$\mathbf{r}$ adalah tingkat ketimpangan investasi PMDN di provinsi - i, $\mathbf{I}_{\mathbf{i}}$ adalah nilai investasi PMDN di provinsi - i, I adalah nilai investasi PMDN total, $\mathbf{f}_{\mathbf{i}}$ adalah jumlah penduduk di provinsi i, $\mathbf{n}$ adalah jumlah total penduduk

Analisis kesenjangan investasi PMDN di sini adalah nilai investasi PMDN yang telah disetujui pemerintah. Analisis kesenjangan investasi PMDN di Gorontalo ditinjau dan dibandingkan dalam lingkup perekonomian di kawasan timur Indonesia (KATIMIN) maupun kawasan pulau Sulawesi. Analisis kesenjangan investasi PMDN di Gorontalo dalam lingkup perekonomian di kawasan pulau Sulawesi dapat dilihat pada Tabel 4 .

Hasil analisis kesenjangan investasi PMDN provinsi Gorontalo yang disetujui pemerintah menunjukkan kecenderungan berfluktuasi dari tahun ke tahun dalam konteks perekonomian di pulau Sulawesi. Kesenjangan (gap) investasi PMDN dilihat dalam kaitan dengan nilai investasi PMDN Gorontalo dibandingkan dengan nilai investasi di seluruh provinsi di pulau Sulawesi yang meliputi provinsi Sulawesi Utara, Gorontalo, Sulawesi Selatan, Sulawesi Barat, Sulawesi Tengah, dan Sulawesi Tenggara. Kesenjangan (gap) investasi PMDN yang disetujui pemerintah di provinsi Gorontalo dibandingkan dengan total investasi di pulau Sulawesi ditunjukkan dengan nilai pada kolom $\left(I_{i}-I\right)$. Pada tahun 2001 yaitu pada saat kebijakan pemekaran wilayah provinsi Gorontalo diadakan besarnya kesenjangan (gap) sebesar -18.305,7. Kemudian pada tahun 2002 yaitu satu tahun pascakebijakan pemekaran wilayah provinsi Gorontalo dari wilayah provinsi Sulawesi Utara besarnya gap menjadi $-3.485,7$ artinya bahwa kebijakan pemekaran wilayah provinsi Gorontalo dari provinsi Sulawesi Utara dalam konteks perekonomian di Sulawesi mempunyai dampak yang cukup besar dalam menurunkan kesenjangan (gap) investasi PMDN di Gorotalo. Penurunan kesenjangan (gap) investasi PMDN terus berlanjut sampai tahun 2003 dan 2004 di mana besarnya kesenjangan -2970.2 dan -2.859,3. Tetapi pada tahun 2007 kesenjangan meningkat tajam menjadi -7802.4 artinya investasi PMDN di Gorontalo pascakebijakan pemekaran wilayah dalam jangka pendek dan menengah relatif kesenjangannya menurun namun dalam jangka panjang cenderung ada peningkatan.

Untuk menjelaskan lebih jauh mengenai kesenjangan investasi di provinsi Gorontalo, maka dianalisis dengan instrumen rasio kesenjangan investasi PMDN (r) yang mengukur besarnya investasi PMDN di provinsi Gorontalo dibandingkan dengan nilai investasi total di pulau Sulawesi dikaitkan dengan jumlah penduduk. Nilai kesenjangan investasi PMDN (r) di provinsi Gorontalo pada saat diterapkan kebijakan pemekaran wilayah pada tahun 2001 relatif tinggi ditunjukkan dengan nilai $\mathrm{r}$ yang cukup besar yaitu 18.762.239. Pascakebijakan pemekaran wilayah yaitu pada tahun 2002 rasio kesenjangan investasi PMDN turun menjadi

Tabel 4. Analisis Kesenjangan Investasi PMDN Provinsi Gorontalo dalam Konteks Perekonomian Sulawesi

\begin{tabular}{|c|c|c|c|c|c|c|}
\hline Tahun & $I_{i}-I$ & $\left(I_{i}-I\right)^{2}$ & $f_{i}$ & $n$ & $f_{i} / n$ & $r=\left(I_{i}-I\right)^{2} x \frac{f_{i}}{n}$ \\
\hline 2000 & $-31934,1$ & 1019786743 & 833600 & 14881371 & 0,056016 & 57124725 \\
\hline 2001 & $-18305,7$ & 335098652 & 845200 & 15095500 & 0,05599 & 18762239 \\
\hline 2002 & $-3485,7$ & 12150104 & 856900 & 15312700 & 0,05596 & 679920,89 \\
\hline 2003 & $-2970,2$ & 8822088 & 868800 & 15532700 & 0,055934 & 493451,24 \\
\hline 2004 & $-2859,3$ & 8175596,5 & 880900 & 15755900 & 0,055909 & 457091,18 \\
\hline 2005 & $-4034,5$ & 16277190 & 893100 & 15981900 & 0,055882 & 909601,4 \\
\hline 2006 & $-4578,7$ & 20964494 & 904100 & 16194200 & 0,055829 & 1170419 \\
\hline 2007 & $-7802,4$ & 60877446 & 915300 & 16409100 & 0,05578 & 3395745,4 \\
\hline
\end{tabular}

Sumber: BPS, (diolah)

Keterangan: $\mathbf{r}$ adalah tingkat ketimpangan investasi PMDN di provinsi Gorontalo, $\mathbf{I}_{\mathbf{i}}$ adalah nilai investasi PMDN yang disetujui pemerintah di provinsi Gorontalo, $\mathbf{I}$ adalah nilai investasi PMDN total di Sulawesi, $\mathbf{f}_{\mathbf{i}}$ adalah jumlah penduduk di provinsi Gorontalo, $\mathbf{n}$ adalah jumlah total penduduk Sulawesi 
679.920,89. Gejala kesenjangan terus berlanjut pada tahun 2003 sebesar 493.451,24, dan tahun 2004 turun lagi menjadi 457.091,18. Tetapi mulai tahun 2005 dan seterusnya ada gejala peningkatan rasio kesenjangan investasi dimana pada tahun 2005 besarnya rasio kesenjangan sebesar 909.601,4 dan pada tahun 2006 naik lagi menjadi 1.170 .419 artinya bahwa kebijakan pemekaran wilayah provinsi Gorontalo dari wilayah provinsi Sulawesi Utara dalam jangka pendek dan menengah berpengaruh terhadap penurunan kesenjangan investasi namun dalam jangka panjang ada kecenderungan peningkatan rasio kesenjangan investasi PMDN.

Untuk lebih melengkapi informasi mengenai dampak kebijakan pemekaran wilayah provinsi Gorontalo dari Sulawesi Utara, maka perlu dianalisis kesenjangan investasi PMDN provinsi Gorontalo dalam konteks perekonomian di kawasan timur Indonesia (KATIMIN). Kawasan timur Indonesia (KATIMIN) di sini meliputi pulau Sulawesi, Pulau Maluku dan Maluku Utara, NTT, NTB, Papua, dan Papua Barat. Tabel 5 menunjukkan besarnya nilai kesenjangan investasi PMDN di Gorontalo yang disetujui pemerintah dalam konteks perekonomian di kawasan timur Indonesia (KATIMIN).

Pada Tabel 5 menunjukkan bahwa kesenjangan (gap) investasi PMDN yang disetujui pemerintah di provinsi Gorontalo dibandingkan dengan keseluruhan investasi PMDN di kawasan timur Indonesia (KATIMIN) yaitu pa- da kolom $\left(I_{i}-I\right)$. Dari hasil perhitungan di atas terlihat bahwa kesenjangan (gap) PMDN di Gorontalo dalam konteks perekonomian di KATIMIN mengalami fluktuasi. Kesenjangan (gap) investasi PMDN pada tahun 2000 yaitu satu tahun sebelum adanya kebijakan pemekaran wilayah provinsi Gorontalo sebesar $-919,9$ dan pada tahun 2002 yaitu satu tahun pasca kebijakan pemekaran wilayah menurun menjadi $-305,4$ artinya bahwa kebijakan pemekaran wilayah menyebabkan penurunan kesenjangan (gap) investasi PMDN pada tahun pertama. Namun pada tahun ke dua (2003) mengalami peningkatan kesenjangan yang sangat tajam menjadi -27.999,5 artinya dampak dari kebijakan pemekaran wilayah terhadap kesenjangan regional di Gorontalo mempunyai dampak yang besar. Tetapi kemudian pada tahun selanjutnya yaitu 2004 mengalami penurunan kesenjangan yang besar menjadi -184,1 artinya kebijakan pemekaran wilayah berfluktuasi mengikuti dinamika perekonomian baik di tingkat lokal di provinsi Gorontalo maupun secara regional di kawasan timur Indonesia (KATIMIN).

Analisis kesenjangan investasi PMDN yang disetujui pemerintah di provinsi Gorontalo menjadi jelas dengan melihat rasio $r$ yang menunjukkan kesenjangan investasi dikaitkan dengan jumlah penduduk. Rasio kesenjangan investasi PMDN di Gorontalo dalam konteks analisis kesenjangan investasi di kawasan timur Indonesia (KATIMIN) sebelum diterapkannya

Tabel 5. Analisis Kesenjangan Investasi PMDN Provinsi Gorontalo dalam Konteks Perekonomian di Kawasan Timur Indonesia (KATIMIN)

\begin{tabular}{|c|c|c|c|c|c|c|}
\hline Tahun & $I_{i}-I$ & $\left(I_{i}-I\right)^{2}$ & $f_{i}$ & $n$ & $f_{i} / n$ & $r=\left(I_{i}-I\right)^{2} x \frac{f_{i}}{n}$ \\
\hline 2000 & -32854 & 1079385316 & 833600 & 26822371 & 0,031079 & 33545714,49 \\
\hline 2001 & $-23630,8$ & 558414708,6 & 845200 & 27233200 & 0,031036 & 17330762,15 \\
\hline 2002 & $-3791,1$ & 14372439,21 & 856900 & 27650500 & 0,03099 & 445407,6114 \\
\hline 2003 & $-30969,7$ & 959122318,1 & 868800 & 28073500 & 0,030947 & 29682279,37 \\
\hline 2004 & $-3043,4$ & 9262283,56 & 880900 & 28503000 & 0,030906 & 286255,6779 \\
\hline 2005 & $-5797,4$ & 33609846,76 & 893100 & 28938700 & 0,030862 & 1037259,937 \\
\hline 2006 & $-5390,8$ & 29060724,64 & 904100 & 29341400 & 0,030813 & 895451,5172 \\
\hline 2007 & $-28524,3$ & 813635690,5 & 915300 & 29749800 & 0,030767 & 25032798,46 \\
\hline
\end{tabular}

Sumber: BPS, (diolah)

Keterangan: $\mathbf{r}$ adalah Tingkat ketimpangan investasi PMDN di provinsi Gorontalo, $\mathbf{I}_{\mathbf{i}}$ adalah Nilai investasi PMDN yang disetujui pemerintah di provinsi Gorontalo, I adalah Nilai investasi PMDN total di Kawasan Timur Indonesia (KATIMIN), $\mathbf{f}_{\mathbf{i}}$ adalah jumlah penduduk di provinsi Gorontalo, $\mathbf{n}$ adalah Jumlah total penduduk di Kawasan Timur Indonesia (KATIMIN) 
kebijakan pemekaran wilayah pada tahun 2000 sebesar 33.545.714,49. Pada tahun 2002 yaitu satu tahun setelah kebijakan pemekaran wilayah provinsi Gorontalo dari provinsi Sulawesi Utara pada tahun 2000 nilai $r$ turun menjadi 445.407,6114. Namun pada tahun 2003 rasio kesenjangan investasi PMDN di Gorontalo naik tajam menjadi 29.682.279,37 dan pada tahun 2004 turun lagi menjadi 286.255,6779 artinya bahwa kebijakan pemekaran wilayah provinsi Gorontalo dari provinsi Sulawesi Utara mengalami fluktuasi mengikuti perubahan kondisi lokal di daerah pemekaran.

Analisis Kesenjangan Investasi PMA di Gorontalo. Daerah pemekaran membutuhkan suntikan dana besar untuk mendorong pengembangan potensi ekonominya. Peranan investasi PMA sangat penting dalam pengembangan perekonomian Indonesia pada umumnya dan di daerah pada khususnya untuk menciptakan lapangan kerja, meningkatkan produksi barang dan jasa, mendorong peningkatan nilai tambah dan meningkatkan kesejahteraan masyarakat. Masuknya investasi PMA di daerah - terutama daerah pemekaran - akan menimbulkan efek berganda (multiplier effect) bagi pengembangan ekonomi lokal melalui transformasi teknologi, pengembangan ekonomi unggulan dan penciptaan nilai tambah perekonomian daerah. Analisis kesenjangan investasi PMA di provinsi Gorontalo ditinjau dalam konteks perekonomian di Sulawesi dan di kawasan timur Indonesia (KATIMIN) meng- alami dinamika yang cukup signifikan. Dalam analisis kesenjangan investasi PMA di sini adalah nilai investasi PMA yang telah disetujui pemerintah. Analisis kesenjangan investasi PMA di provinsi Gorontalo dalam lingkup perekonomian di kawasan pulau Sulawesi dapat dilihat pada Tabel 6.

Hasil analisis kesenjangan investasi PMA provinsi Gorontalo menunjukkan kecenderungan berfluktuasi dari tahun ke tahun. Penelitian di atas menjelaskan mengenai investasi PMA yang disetujui pemerintah dan dalam konteks perbandingan antara investasi di Gorontalo dengan nilai investasi PMA di seluruh Sulawesi. Kesenjangan (gap) investasi PMA dilihat dalam kaitan dengan nilai total investasi di Gorontalo dibandingkan dengan nilai investasi di seluruh provinsi di pulau Sulawesi yang meliputi provinsi Sulawesi Utara, Sulawesi Selatan, Gorontalo, Sulawesi Barat, Sulawesi Tengah, dan Sulawesi Tenggara. Kesenjangan (gap) investasi PMA yang disetujui pemerintah di provinsi Gorontalo dibandingkan dengan total investasi di pulau Sulawesi ditunjukkan dengan nilai pada kolom $\left(I_{i}-I\right)$. Pada tahun 2000 yaitu satu tahun sebelum kebijakan pemekaran wilayah provinsi Gorontalo dari provinsi Sulawesi Utara besarnya kesenjangan (gap) sebesar -74,2. Kemudian pada tahun 2001 yaitu pada saat kebijakan pemekaran wilayah provinsi Gorontalo diterapkan besarnya gap menjadi $-81,1$ ada sedikit kenaikan. Kemudian pada tahun 2002 kesenjangan meningkat menjadi -420,7, keada-

Tabel 6. Analisis Kesenjangan Investasi PMA Provinsi Gorontalo dalam Konteks Perekonomian Sulawesi

\begin{tabular}{lrrrrrr}
\hline Tahun & $\boldsymbol{I}_{\boldsymbol{i}} \boldsymbol{-} \boldsymbol{I}$ & \multicolumn{1}{c}{$\left(\boldsymbol{I}_{\boldsymbol{i}}-\boldsymbol{I}\right)^{\mathbf{2}}$} & \multicolumn{1}{c}{$f_{i}$} & $\boldsymbol{n}$ & \multicolumn{1}{c}{$f_{i} / \boldsymbol{n}$} & $\boldsymbol{r}=\left(\boldsymbol{I}_{\boldsymbol{i}}-\boldsymbol{I}\right)^{\mathbf{2}} \boldsymbol{x} \frac{f_{\boldsymbol{i}}}{\boldsymbol{n}}$ \\
\hline 2000 & $-74,2$ & 5505,64 & 833600 & 14881371 & 0,134455 & 308,4058 \\
2001 & $-81,1$ & 6577,21 & 845200 & 15095500 & 0,133994 & 368,2593 \\
2002 & $-420,7$ & 176988,49 & 856900 & 15312700 & 0,133536 & 9904,291 \\
2003 & $-425,1$ & 180710,01 & 868800 & 15532700 & 0,133081 & 10107,76 \\
2004 & $-284,2$ & 80769,64 & 880900 & 15755900 & 0,13263 & 4515,767 \\
2005 & $-307,1$ & 94310,41 & 893100 & 15981900 & 0,132175 & 5270,251 \\
2006 & $-347,1$ & 120478,41 & 904100 & 16194200 & 0,131683 & 6726,145 \\
2007 & $-6208,7$ & 38547955,69 & 915300 & 16409100 & 0,131189 & 2150206 \\
\hline
\end{tabular}

Sumber: BPS, (diolah)

Keterangan: $\mathrm{r}$ adalah tingkat ketimpangan investasi PMA di provinsi Gorontalo, $\mathrm{I}_{\mathrm{i}}$ adalah nilai investasi PMA yang disetujui pemerintah di provinsi Gorontalo, I adalah nilai investasi PMA total di Sulawesi, $\mathrm{f}_{\mathrm{i}}$ adalah jumlah penduduk di provinsi Gorontalo, $\mathrm{n}$ adalah jumlah total penduduk Sulawesi 
an ini menyiratkan bahwa kebijakan pemekaran wilayah di Gorontalo berpengaruh terhadap kesenjangan (gap) PMA di Gorontalo. Kondisi ini terus berjalan relatif stabil sampai tahun 2006 kemudian pada tahun 2007 meningkat tajam menjadi -6.208,7. Fakta menunjukkan bahwa kebijakan pemekaran wilayah relatif tidak menimbulkan pengaruh yang berarti namun dalam jangka panjang cenderung menimbulkan kesenjangan (gap) yang cukup berarti.

Untuk menjelaskan lebih jauh mengenai kesenjangan investasi di suatu daerah, maka dianalisis dengan instrumen rasio kesenjangan investasi PMA (r) yang mengukur besarnya investasi PMA di suatu daerah dibandingkan dengan nilai investasi PMA total disuatu wilayah. Nilai rasio kesenjangan ini dikaitkan dengan jumlah penduduk di suatu wilayah dengan jumlah penduduk secara total. Rasio kesenjangan investasi PMA (r) di provinsi Gorontalo sebelum kebijakan pemekaran wilayah pada tahun 2000 relatif cukup baik ditunjukkan dengan nilai r yang cukup kecil yaitu 308.4058. Pada saat kebijakan pemekaran wilayah provinsi Gorontalo dari Sulawesi Utara pada tahun 2001 besarnya nilai kesenjangan investasi PMA relatif stabil yaitu sebesar 368.2593. Pada tahun 2002 meningkat tajam menjadi 9904,291 artinya bahwa kebijakan pemekaran wilayah provinsi Gorontalo berpengaruh terhadap kesenjangan investasi PMA pada tahun pertama.

Analisis kesenjangan investasi PMA provinsi Gorontalo yang disetujui pemerintah da- lam konteks perekonomian di kawasan timur Indonesia (KATIMIN) dikaitkan dengan jumlah penduduk di kawasan tersebut. Kawasan timur Indonesia (KATIMIN) dalam penelitian di sini meliputi pulau Sulawesi, Pulau Maluku, dan Maluku Utara, NTT, NTB, Papua Barat dan Papua. Tabel 7 menunjukkan besarnya nilai kesenjangan investasi PMA yang disetujui pemerintah dalam konteks perekonomian di kawasan timur Indonesia (KATIMIN).

Pada Tabel 7 dapat dilihat kesenjangan (gap) investasi PMA di provinsi Gorontalo dibandingkan dengan investasi secara total di kawasan timur Indonesia (KATIMIN) yang ditunjukkan pada kolom $\left(I_{i}-I\right)$.. Nilai investasi PMA di sini adalah yang disetujui oleh pemerintah. Dari tabel di atas terlihat bahwa gap investasi PMA di provinsi Gorontalo dibandingkan dengan besarnya investasi PMA secara total di kawasan timur Indonesia (KATIMIN) mengalami fluktuasi dari tahun ke tahun. Kesenjangan (gap) investasi PMA pada tahun 2000 yaitu satu tahun sebelum adanya kebijakan pemekaran wilayah provinsi Gorontalo dari provinsi Sulawesi Utara sebesar -1741.2. Kemudian pada tahun 2001 berubah menjadi -6710.8 artinya bahwa kebijakan pemekaran wilayah dan pada tahun ke dua (2003) mengalami peningkatan menjadi -2288.1 artinya dampak dari kebijakan pemekaran wilayah terhadap kesenjangan regional berangsur-angsur berkurang seiring adanya kebijakan penunjang di daerah seperti kemudahan dalam berinvestasi dan

Tabel 7. Analisis Kesenjangan Investasi PMA Provinsi Gorontalo dalam Konteks Perekonomian di Kawasan Timur Indonesia (KATIMIN)

\begin{tabular}{|c|c|c|c|c|c|c|}
\hline Tahun & $I_{i}-I$ & $\left(I_{i}-I\right)^{2}$ & $f_{i}$ & $n$ & $f_{i} / n$ & $r=\left(I_{i}-I\right)^{2} x \frac{f_{i}}{n}$ \\
\hline 2000 & $-1741,2$ & 3031777,44 & 833600 & 26822371 & 0,031079 & 94223,20174 \\
\hline 2001 & $-6710,8$ & 45034836,64 & 845200 & 27233200 & 0,031036 & 1397685,323 \\
\hline 2002 & $-708,5$ & 501972,25 & 856900 & 27650500 & 0,03099 & 15556,31981 \\
\hline 2003 & $-2288,1$ & 5235401,61 & 868800 & 28073500 & 0,030947 & 162021,7258 \\
\hline 2004 & $-829,4$ & 687904,36 & 880900 & 28503000 & 0,030906 & 21260,04107 \\
\hline 2005 & $-582,1$ & 338840,41 & 893100 & 28938700 & 0,030862 & 10457,22061 \\
\hline 2006 & $-798,1$ & 636963,61 & 904100 & 29341400 & 0,030813 & 19626,83443 \\
\hline 2007 & -6656 & 44302336 & 915300 & 29749800 & 0,030767 & 1363031,958 \\
\hline
\end{tabular}

Sumber BPS, (diolah)

Keterangan: $\mathrm{r}$ adalah tingkat ketimpangan investasi PMA di provinsi Gorontalo, $\mathrm{I}_{\mathrm{i}}$ adalah nilai investasi PMAyang disetujui pemerintah di provinsi Gorontalo, I adalah nilai investasi PMA total di Kawasan Timur Indonesia (KATIMIN), $\mathrm{f}_{\mathrm{i}}$ adalah jumlah penduduk di provinsi Gorontalo, $\mathrm{n}$ adalah jumlah total penduduk di Kawasan Timur Indonesia (KATIMIN) 
penurunan bea dan pajak daerah. Pada tahuntahun selanjutnya kesenjangan investasi PMA berfluktuasi mengikuti dinamika perekonomian baik di tingkat lokal di provinsi Sulawesi Utara maupun secara global di kawasan timur Indonesia (KATIMIN).

Analisis kesenjangan investasi PMA di provinsi Gorontalo dalam konteks perekonomian di kawasan timur Indonesia (KATIMIN) menjadi jelas dengan melihat nilai rasio kesenjangan investasi $r$ yang menunjukkan kesenjangan investasi dikaitkan dengan jumlah penduduk. Nilai rasio kesenjangan investasi PMA di Gorontalo dalam konteks analisis kesenjangan investasi di kawasan timur Indonesia (KATIMIN) sebelum diterapkannya kebijakan pemekaran wilayah pada tahun 2000 sebesar 94223,20174 . Pada tahun 2001 nilai $r$ turun menjadi 1397685,323 artinya bahwa kebijakan pemekaran wilayah provinsi Gorontalo dari provinsi Sulawesi Utara mengalami penurunan kesenjangan investasi PMA. Keadaan ini terus mengalami fluktuasi sampai tahun 2003 dan pada tahun 2004 nilai $r$ turun tajam menjadi 21260,04107 . Kemudian pada tahun verikutnya yaitu dari 2005 mengalami peningkatan sangat tajam menjadi 10457,22061. Hasil penelitian ini menyiratkan bahwa dampak dari kebijakan pemekaran wilayah provinsi Gorontalo dari provinsi Sulawesi Utara dalam jangka pendek relatif belum menunjukkan pengaruh yang berarti namun dalam jangka menengah dan panjang berpengaruh cukup besar terhadap kesenjangan investasi PMA dalam konteks perekonomian di kawasan timur Indonesia (KATIMIN).

\section{SIMPULAN}

Kebijakan pemekaran wilayah menjadi salah satu alternatif solusi untuk mendorong pertumbuhan ekonomi daerah di Indonesia. Permasalahan utama dalam pembangunan ekonomi pada daerah pemekaran adalah bagaimana menyiapkan kerangka kebijakan yang dapat mendorong penyediaan infrastruktur dan SDM yang memadai. Rendahnya ketersediaan infrastruktur dan kurang memadainya kualitas SDM menjadi kendala utama pembangungan di daerah pemekaran seperti halnya di provinsi Gorontalo. Kebijakan pemekaran wilayah di provinsi Sulawesi Utara menjadi dua provinsi yaitu Sulawesi Utara dan Gorontalo memberikan dampak yang bervariasi antara konteks ekonomi di kawasan pulau Sulawesi dan kawasan timur Indonesia. Kesenjangan investasi juga berbeda antara satu tahun dengan tahun berikutnya baik PMA maupun PMDN, sehingga diperlukan peningkatan kinerja dan koordinasi antarlembaga untuk meningkatkan iklim investasi di provinsi Sulawesi Utara. Dampak dari pemekaran wilayah yang ditimbulkan juga tidak sama dari waktu ke waktu. Namun yang jelas kebijakan pemekaran wilayah bagi daerah induk menyebabkan pengurangan sumber daya baik SDM, SDA, infrastruktur, jaringan, dan sebagainya, sehingga diperlukan upaya meningkatkan kerjasama dan sinergi baik dengan provinsi Gorontalo sebagai daerah pemekarannya maupun dengan daerah lain termasuk dengan pemerintah pusat. Ketersediaan jaringan infrastruktur merupakan kendala utama untuk meningkatkan iklim investasi di provinsi Sulawesi Utara sehingga investor PMA dan PMDN mau berinvestasi di daerah tersebut. Faktor lain yang mempengaruhi terhadap implikasi kebijakan pemekaran wilayah terhadap kesenjangan antardaerah di samping ketersediaan infrastruktur juga dipengaruhi oleh pemerataan jumlah penduduk antarwilayah di Sulawesi Utara. Karena tentu saja dengan cakupan wilayah yang semakin sempit memberi ruang bagi penduduk yang semakin sedikit untuk beraktivitas ekonomi. Provinsi Gorontalo berpotensi menjadi provinsi yang maju melalui pembangunan sektor agroindustri, perikanan, perkebunan dan UMKM. Integrasi dan koordinasi antarbidang dalam pemerintahan dan keterlibatan pihak pengusaha dan stakeholders menjadi kata kunci untuk mendorong pertumbuhan ekonomi di daerah pemekaran wilayah ini.

\section{DAFTAR PUSTAKA}

Anwar, Arsyad. 1985. Prospek dan Permasalahan Ekonomi Indonesia 1985-1986, edisi perta- 
ma. Jakarta: Fakultas Ekonomi Universitas Indonesia dan Sinar Harapan.

Asmara, H. 1986. Perencanaan dan Pembangunan di Indonesia. Jakarta: Penerbit PT Gramedia.

Badan Pusat Statistik. 2007. Kabupaten Sulawesi Utara dalam Angka. Sulawesi Utara: BPS.

Bidani, B, and M. Ravallion. 1993. A Regional Poverty Profile for Indonesia. Bulletin of Indonesian Economic Studies, 29 (3), 37 - 68

Boediono. 1979. Econometric Models of the Indonesian Economy for Short Run Policy Analysis. Disertation Ph.D, University of Pensylvania.

Branson, William H. 2000. Macroeconomic Theory and Policy, third edition. New York: Harper and Row Publisher.

Edy Suandi Hamid. 2005. Formula Alternatif Dana Alokasi Umum (DAU) Upaya Mengatasi Ketimpangan Fiskal dalam Era Otonomi Daerah. Yogyakarta: UII Press.
Glassburner, Bruce dan Chandra Aditiawan. 1982. Teori dan Kebijaksanaan Ekonomi Makro, Edisi kedua. Jakarta: LP3ES.

Godet. 1994. Structural Analysis Methods Using Qualitative Approach Toward Economics Investment. Journal of Economics Sciences, vol. 7

Hit, Ireland, Hokisson. 1999. Policy Analysis Models and Concept for Building Competences. Engelwood Cliff: Prentice Hall.

Kuznets, S. 1955. Economic Growth and Income Inequality. American Economic Review, 45, 1-28.

Nurzaman, SS. 2007. Perencanaan Wilayah dalam Sistem yang Dinamis. Bahan kuliah Prodi Perencanaan Wilayah dan Kota, SAPPK, Bandung: ITB.

William C. Blanchfield. 1976. Economic Development. Ohio: Copyright Grid, Inc. 